\title{
KOIMITIMEN PROFESI DAN PENGARUHNYA TERHADAP KOMPETENSI PROFESIONAL GURU PADA MADRASAH TSANAWIYAH DI KOTA MAKASSAR
}

\author{
Wahyuddin Naro \\ Fakultas Tarbiyah dan Keguruan UIN Alauddin Makassar \\ J1. H.M. Yasin Limpo No. 36 Samata-Gowa \\ Email: dr.akusmana@gmail.com
}

\begin{abstract}
Teachers are key to improving the quality of education, they are at the central point of any educational reform effort. In order to become a professional person, teachers must meet the qualifications and competency standards of educators. The approach used in this study is a multidisciplinary approach that is: religious approach, juridical / normative, management, and sociological. This research was conducted in Makassar City of South Sulawesi Province. The place of research is in all Madrasah Tsanawiyah within the Ministry of Religious Affairs of Makassar City. The object population (target) of this research is all teachers of Madrasah Tsanawiyah in Makassar City consisting of 2 State Islamic Madrasah Tsanawiyah and 32 Private Madrasah Tsanawiyah. The teacher population of 34 Madrasah Tsanawiyah in Makassar City is 729 people. Research Results Shows that the professionalism of Madrasah Tsanawiyah teachers in terms of; 1) Mastery of materials, structures, concepts, and scientific patterns that support the subjects being taught, 2) Mastery of Competency Standards and Basic Competencies, 3) Development of creativity-enhanced learning materials, and 4) Continuous professional development by taking reflective action yet Optimal because it is in the category of being.
\end{abstract}

Keywords: Professional Commitment, Professional Teacher Competence

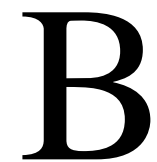
erbagai upaya dilakukan oleh pemerintah untuk memajukan pendidikan di Indonesia, termasuk pendidikan pada madrasah, yang ditandai dengan dikeluarkannya berbagai peraturan perundangan sebagai landasan untuk melakukan perubahan dan perbaikan kualitas pendidikan. Oleh karena itu, pendidikan agama Islam mempunyai peranan yang sangat besar bagi penyiapan sumber daya manusia Indonesia yang berkualitas, yang dewasa ini dituntut tidak hanya menguasai ilmu-ilmu agama melainkan juga ilmu pengetahuan dan teknologi serta penguasaan keterampilan yang berguna bagi pengembangan masyarakat.

Eksistensi pendidikan agama Islam pada satu sisi mempunyai kedudukan yang sangat penting dalam sistem pendidikan nasional dengan lahirnya Undang-Undang Republik Indonesia Nomor 20 Tahun 2003 tentang Sistem Pendidikan Nasional (Sisdiknas). Bahkan, dengan Undang-Undang Republik Indonesia Nomor 20 Tahun 
2003 tersebut pada Bab VI pasal 17 dan 18, disebutkan kedudukan madrasah sama dengan sekolah umum. (Departemen Agama RI, 2007: 17).

Madrasah sebagai institusi pendidikan tidak dapat mengelak dari kebijaksanaan reformasi pendidikan yang bersifat desentralistik. (Kunandar, 2007: 104). Manajemen berbasis sekolah di lingkungan madrasah merupakan bentuk pengelolaan pendidikan yang ditandai dengan otonomi yang luas pada tingkat madrasah yang disertai semakin meningkatnya partisipasi masyarakat.

Dewasa ini berbagai cara dilakukan untuk meningkatkan mutu guru yang telah bertugas di sekolah dan madrasah melalui pendidikan dalam jabatan (in-service training). Tujuannya adalah untuk meningkatkan keterampilan mengajar, penguasaan terhadap materi ajar, serta komitmen dan motivasi guru dalam melakukan proses pembelajaran. Di antara keseluruhan komponen dalam pembelajaran, guru merupakan komponen organik yang sangat menentukan. Guru merupakan sumber daya manusia yang sangat menentukan keberhasilan pembelajaran.

Guru merupakan unsur pendidikan yang sangat dekat dengan peserta didik dalam upaya pendidikan sehari-hari dan banyak menentukan keberhasilan peserta didik dalam mencapai tujuan. Peranan guru semakin penting dalam era global. Hanya melalui bimbingan yang profesional, setiap peserta didik dapat menjadi sumber daya manusia yang berkualitas, kompetitif, dan produktif sebagai aset nasional dalam menghadapi persaingan yang makin ketat dan berat, sekarang dan di masa yang akan datang. (Ditjen Dikdasmen Depdiknas, 2002: 7.)

Begitu sangat strategisnya kedudukan guru sebagai tenaga profesional, di dalam Undang-Undang Republik Indonesia Nomor 14 Tahun 2005 tentang Guru dan Dosen, tepatnya Bab III Pasal 7, diamanatkan bahwa profesi guru merupakan bidang pekerjaan khusus yang dilaksanakan berdasarkan prinsip sebagai berikut: (a) memiliki bakat, minat, panggilan jiwa, dan idealisme; (b) memiliki komitmen untuk meningkatkan mutu pendidikan, keimanan, ketakwaan, dan akhlak mulia (c) memiliki kualifikasi akademik dan latar belakang pendidikan sesuai dengan bidang tugas; (d) memiliki kompetensi yang diperlukan sesuai dengan bidang tugas; (e) memiliki tanggung jawab atas pelaksanaan tugas keprofesionalan; (f) memperoleh penghasilan yang ditentukan sesuai dengan prestasi kerja; (g) memiliki kesempatan untuk mengembangkan keprofesionalan secara berkelanjutan dengan belajar sepanjang hayat; (h) memiliki jaminan perlindungan hukum dalam melaksanakan tugas keprofesionalan; dan (i) memiliki organisasi profesi yang mempunyai kewenangan mengatur hal-hal yang berkaitan dengan tugas keprofesionalan guru. (UU RI Nomor 14 Tahun 2005, Bab III Pasal 7).

Faktanya, menjadi guru tidak cukup sekadar untuk memenuhi panggilan jiwa, tetapi juga memerlukan seperangkat keterampilan dan kemampuan khusus dalam bentuk penguasaan kompetensi guru, sesuai dengan kualifikasi jenis dan jenjang pendidikannya. Guru merupakan pendidik profesional dengan tugas utama mendidik, mengajar, membimbing, mengarahkan, melatih, menilai, dan mengevaluasi peserta 
didik pada jalur pendidikan formal. (Departemen Agama RI: 73). Tugas utama itu akan efektif jika guru memiliki derajat profesional tertentu yang tercermin dari komitmen terhadap kompetensi, kemahiran, kecakapan, atau keterampilan yang memenuhi standar mutu.

Rendahnya mutu pendidikan telah memberikan akibat langsung pada rendahnya mutu sumber daya manusia bangsa Indonesia. Proses untuk melahirkan sumber daya manusia yang bermutu hanya bisa malalui jalur pendidikan dan proses pembelajaran yang bermutu pula.

Mutu pendidikan ditentukan oleh sistem pendidikan, baik dari segi pengelolaan maupun proses pendidikan itu sendiri, diarahkan secara efektif untuk mening-katkan nilai tambah dari faktor-faktor input agar menghasilkan output setinggi-tingginya. Faktor input pendidikan terdiri dari: (1) peserta didik, (2) tenaga kependidikan termasuk guru, anggaran, kurikulum, sarana prasarana dan administrasi, (3) lingkungan yang meliputi faktor sosial ekonomi, politik, dan keamanan (Ace Suryadi \& Wiana Mulyana, 1992: 49).

Peningkatan mutu pendidikan ditentukan oleh seberapa jauh para pelaku pendidikan melaksanakan tugas dan tanggung jawab mengelola pendidikan. Brandt dalam Supriadi menyatakan, guru merupakan kunci dalam peningkatan mutu pendidikan, mereka berada di titik sentral dari setiap usaha reformasi pendidikan yang diarahkan pada perubahan-perubahan kualitatif. Setiap usaha peningkatan mutu pendidikan seperti pembaruan kurikulum, pengembangan metode mengajar, penyediaan saran dan prasarana hanya akan berarti apabila melibatkan guru (Dedi Supriadi, 1999: $52)$.

Peningkatan kompetensi profesional bagi guru sangat penting agar guru peka dan tanggap terhadap perubahan-perubahan, pembaruan serta perkembangan ilmu pengetahuan dan teknologi yang demikian cepat.

Setiap usaha peningkatan kompetensi profesional guru akan memberi hasil yang baik jika diikuti oleh komitmen dan motivasi guru untuk meningkatkan dan mengembangkan kemampuannya sendiri. Asrorun Ni'am mengungkapkan bahwa upaya peningkatan kompetensi guru harus mendasarkan pada kemauan dan kemampuan guru. Artinya, guru tidak harus didikte dan diberi berbagai arahan dan instruksi. Oleh karena itu, perlu disusun standar profesional guru yang akan dijadikan acuan pengembangan mutu guru. (Ibrahim Bafadal \& A. Imron, 2004: 51). Glickman dalam Bafadal menyebutkan aspek pada guru yang menentukan orientasi profesionalnya, yaitu komitmen guru (teacher's commitment), aspek tersebut harus melekat pada diri seorang guru, karena ia akan menentukan tipe guru tersebut dalam melaksanakan proses pembelajara (Asrorun Ni'am Sholeh, 2006: 42). Hal lain diungkapkan oleh Asrorun Ni'am bahwa yang mengakibatkan rendahnya pengakuan masyarakat terhadap profesi guru yakni kelemahan yang terdapat pada diri guru itu sendiri, di antaranya rendahnya kemampuan untuk bekerja secara profesional (Asrorun Ni'am Sholeh, 2006: 42). 
Guru merupakan kunci dalam peningkatan mutu pendidikan dan mereka berada di titik sentral dari setiap usaha reformasi pendidikan yang diarahkan pada perubahanperubahan kualitatif. Setiap usaha peningkatan mutu pendidikan seperti perubahan kurikulum, pengembangan metode-metode pembelajaran, penyediaan sarana dan prasarana akan berarti apabila melibatkan guru.

Madrasah yang sebagian besar swasta tersebut diupayakan agar dapat memenuhi standar nasional pendidikan, mengejar ketertinggalan dibandingkan dengan sekolah umum yang sebagian besar negeri. Upaya peningkatan kualitas pendidikan pada madrasah, baik mengenai pengembangan kurikulum, peningkatan profesionali-tas guru, pemenuhan kebutuhan sarana prasarana dan pemberdayaan pendidikan kini telah, sedang, dan akan dilaksanakan secara terus menerus (Abdul Rahman Saleh, 2004: 88). Apabila setiap lembaga penyelenggara pendidikan selalu berupaya untuk memberikan jaminan kualitas ini secara terus menerus maka diharapkan kualitas pendidikan pada madrasah secara keseluruhan di seluruh Indonesia akan terus meningkat. Peningkatan kualitas pendidikan pada madrasah semacam itu akan berdampak pada peningkatan kualitas sumber daya manusia secara nasional.

Agar menjadi orang yang profesional, guru harus memenuhi standar kualifikasi dan kompetensi tenaga pendidik, di samping 7 standar lainnya sebagaimana ketentuan yang ditegaskan dalam Undang-undang RI Nomor 20 Tahun 2003 tentang Sisdiknas dan Peraturan Pemerintah (PP) Nomor 19 Tahun 2005 tentang Standar Nasional Pendidikan (SNP), serta memperhatikan ketentuan lainnya berkaitan dengan tenaga kependidikan.

Menurut PP RI Nomor 19 Tahun 2005 Pasal 28: Ayat 1. Pendidik harus memiliki kualifikasi akademik dan kompetensi sebagai agen pembelajaran, sehat jasmani dan rohani, serta memiliki kemampuan untuk mewujudkan tujuan pendidikan nasional. Ayat 2. Kualifikasi akademik sebagaimana dimaksud pada ayat 1 adalah tingkat pendidikan minimal yang harus dipenuhi oleh seorang pendidik yang dibuktikan dengan ijazah dan/atau sertifikat keahlian yang relevan sesuai ketentuan perundang-undangan yang berlaku. (Departemen Agama RI: 153).

Upaya peningkatan mutu pembelajaran akan optimal jika guru memiliki kompetensi profesional dan berperan serta secara aktif dalam proses pembinaan dan pengembangan pendidikan. Hal ini sejalan dengan Undang-undang RI Nomor 14 Tahun 2005 tentang Guru dan Dosen bahwa guru adalah pendidik pro-fesional dengan tugas utama mendidik, mengajar, membimbing, mengarahkan, melatih, menilai, dan mengevaluasi peserta didik. (Departemen Agama RI: 73).

Selanjutnya dalam Peraturan Pemerintah RI Nomor 19 tahun 2005 tentang Standar Nasional Pendidikan bahwa guru sebagai agen pembelajaran pada jenjang pendidikan dasar dan menengah serta pendidikan anak usia dini harus memiliki kompetensi pedagogik, kepribadian, profesional, dan sosial. (Departemen Agama RI: 78). Terkait dengan kompetensi guru tersebut, di dalam Penjelasan Undang-undang 
Nomor 14 Tahun 2005 tentang Guru dan Dosen, pasal 10 ayat (1) diterangkan sebagai berikut: yang dimaksud dengan kompetensi pedagogik adalah kemampuan dalam mengelola pembelajaran peserta didik; yang dimaksud dengan kompetensi kepribadian adalah kemampuan kepribadian yang mantap, berakhlak mulia, arif dan berwibawa serta menjadi teladan peserta didik; yang dimaksud dengan kompetensi profesional adalah kemampuan penguasaan materi pelajaran secara luas dan mendalam; serta yang dimaksud dengan kompetensi sosial adalah kemampuan guru untuk berkomunikasi dan berinteraksi secara efektif dan efisien dengan peserta didik, sesama guru, orang tua/wali peserta didik dan masyarakat sekitar. (Ahmadi Syukran Nafis, 2010: 47). Guru adalah profesi, yang berarti suatu jabatan yang memerlukan keahlian khusus sebagai guru dan tidak dapat dilakukan oleh sembarang orang di luar bidang pendidikan. (Sudarwan Danim, 2010: 58).

Terkait dengan latar belakang di atas, menarik untuk dilakukan penelitian dan pengkajian yang mendalam tentang pengaruh komitmen profesi terhadap kompetensi profesional guru Madrasah Tsanawiyah di Kota Makassar, sehingga nantinya dapat menjadi acuan untuk membuat rencana strategis dalam mengoptimalkan profesionalisme guru terhadap peningkatan mutu pembelajaran. Agar kualitas pendidikan pada madrasah sesuai dengan apa yang seharusnya dan apa yang diharapkan, maka pengembangan profesionalitas guru sangat diharapkan dalam rangka peningkatan kualitas sumber daya manusia secara umum.

\section{KAJIAN TEORI}

\section{Pendidikan Madrasah}

Madrasah mempunyai karakter yang sangat spesifik, bukan hanya melaksanakan tugas pendidikan dan pengajaran agama, tetapi juga mempunyai tugas untuk memberikan bimbingan hidup di dalam masyarakat. Madrasah yang membawa fungsi teologis seperti itu, akan paralel dengan kesadaran teologis masyarakat yang dilandasi oleh kebutuhan memperdalam dan mengamalkan ilmu-ilmu agamanya. Oleh karena itu madrasah adalah milik masyarakat dan menyatu dengan nilai-nilai yang telah hidup dan dikembangkan di dalam kebudayaan sebagai milik masyarakat.

Upaya peningkatan kualitas pendidikan pada madrasah, baik mengenai pengembangan kurikulum, peningkatan profesionalitas guru, pemenuhan kebutuhan sarana prasarana maupun pemberdayaan pendidikan, sedang dilakukan dan akan dilakukan secara terus menerus (Depatemen Agama, 2006: 19). Upaya tersebut merupakan agenda pemerintah melalui Kementerian Agama yang diarahkan agar setiap satuan pendidikan madrasah selalu berupaya untuk memberikan jaminan kualitas kepada pihak-pihak yang berkepentingan, yaitu suatu jaminan agar setiap penyelenggara pendidikan di madrasah sesuai dengan apa yang seharusnya dan sesuai pula dengan harapan masyarakat. Esensi sebuah pendidikan di madrasah adalah proses pembelajaran. 
Selanjutnya seiring dengan usaha dalam upaya pembaruan sistem pendidikan menjadi suatu sistem yang lebih relevan dengan kebutuhan kini dan di masa depan, maka madrasah harus siap dan mampu melakukan pengembangan model-model dan atau pola-pola baru dalam hal penyelenggaraan program pendidikan sekaligus menjembatani tuntutan dan tantangan. Tim pengembang Departemen Agama menegaskan bahwa, visi dan misi madrasah harus senantiasa menjadikan anak bangsa ber-iman dan bertakwa kepada Allah swt., berakhlak mulia, memiliki pengetahuan dan keterampilan yang cukup dan memiliki kemampuan menyesuaikan diri dengan lingkungan.

Lebih lanjut Tim Departemen Agama menambahkan, dalam mewujudkan visi tersebut, maka madrasah mengemban visi untuk mengembangkan satuan pendidikan yang berciri:

a. Populis, yakni madrasah selalu dicintai oleh masyarakat, karena tumbuh dari masyarakat dan dikembangkan oleh masyarakat.

b. Islami, yaitu madrasah yang berciri khas agama Islam, mampu menciptakan anakanak bangsa yang beriman dan bertakwa kepada Allah swt. dan berakhlak mulia.

c. Berkualitas, yaitu madrasah yang mampu mencetak anak-anak bangsa yang memiliki kemampuan dan keterampilan dan sanggup menghadapi tantangan jaman. (Departemen Agama, 2007: 70).

Dengan demikian untuk menghadapi dan menyongsong masa depan, diperlukan suatu model sistem pendidikan madrasah yang mengembangkan kemampuan dasar dan pelaksanaan sistem pendidikan berdasarkan prinsip long life education.

\section{Komitmen Profesi}

Komitmen profesi adalah hubungan antara karyawan dengan organisasi yang ditunjukkan dengan adanya keinginan untuk mempertahankan keanggotaan organi-sasi, menerima nilai dan tujuan organisasi serta serta bersedia untuk berusaha keras demi tercapainya tujuan dan kelangsungan organisasi (Panggabean, 2004: 27).

Dalam suatu organisasi profesi seorang anggota organisasi profesi dituntut untuk memiliki komitmen profesi. Menurut Gibson yang dikutip oleh Nurika mendefinisikan komitmen sebagai lingkup, identifikasi, keterlibatan dan loyalitas yang diekspresikan oleh seseorang terhadap organisasinya (Nurika Restuningdiah, 2009: 21).

Beberapa faktor yang dapat menjadi pendukung dalam pelaksanaan komitmen profesi guru yaitu potensi manusia, motivasi kerja, sertifikasi pendidik, kepemimpinan kepala sekolah, dan peranan pengawas pendidikan:

\section{Potensi Manusia}

Peran manusia sebagai khalifah di muka bumi ini memiliki kekuasaan untuk mengolah alam dengan segenap daya dan potensi yang dimilikinya, sekaligus menjalankan kedudukannya sebagai 'abdullah, yang seluruh usaha dan aktivitasnya itu harus dilaksanakan dalam rangka ibadah kepada Allah. Oleh karena itu, maka seorang 
khalifah tidak akan bisa berbuat sesuatu yang mencerminkan kemungkaran atau bertentangan dengan kehendak Tuhan. Pada dasarnya kedudukan manusia di muka bumi sebagai hamba Allah sangat terkait erat dengan perannya. Ketika manusia menyandang kedudukan tersebut, maka Allah swt. akan menuntut agar manusia menjalankan perannya sesuai dengan kedudukannya itu.

\section{Motivasi Kerja}

Motivasi (motivation) berasal dari bahasa latin, yakni movere yang berarti menggerakkan (to move). (J. Winardi, 2007:12). Motivasi adalah dorongan dasar yang menggerakkan seseorang bertingkah laku, dorongan ini berada pada diri seseorang yang menggerak-kan untuk melakukan sesuatu yang sesuai dengan dorongan dalam dirinya. (Hamzah B. Uno: 8).

Motif adalah daya dalam pribadi seseorang yang mendorongnya untuk melakukan sesuatu (Tabrani Rusyan, dkk., 1990: 49). Contohnya, ketika seorang peserta didik rajin belajar, guru hendaknya menyelidiki apa motif yang mendorongnya, demikian sebaliknya ketika seorang peserta didik malas belajar, guru harus menyelidiki mengapa terjadi demikian. Guru hendaknya berperan sebagai pendorong, motivator, agar motifmotif yang baik atau positif dibangkitkan dan atau ditingkatkan dalam diri peserta didik.

Di dalam al-Qur'an, Allah swt. menerangkan bahwa pekerjaan seseorang sangat terkait dengan imbalan/pahala yang diterimanya. Semakin baik pekerjaan seseorang (ikhlas beramal), semakin tinggi imbalan/pahala yang akan diberikan yaitu, QS alTin/95: 6 yang berbunyi:

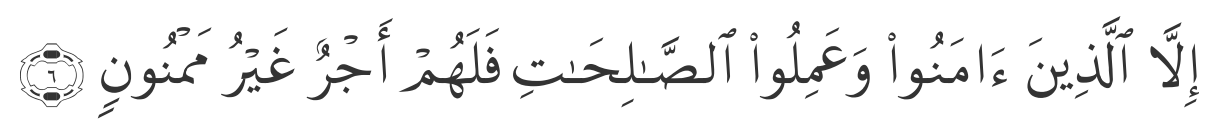

Terjemahnya:

kecuali orang-orang yang beriman dan mengerjakan amal saleh; maka bagi mereka pahala yang tiada putus-putusnya (Departemen Agama RI: 1076).

Ayat tersebut di atas memberikan motivasi seseorang dalam berkarya dengan sebaik-baiknya dengan imbalan yang tak terhingga.

Guru merupakan ujung tombak keberhasilan pendidikan dan dianggap sebagai orang yang berperanan penting dalam pencapaian tujuan pendidikan yang merupakan pencerminan mutu pendidikan. Keberadaan guru dalam melaksanakan tugas dan kewajibannya tidak lepas dari pengaruh faktor internal dan faktor eksternal yang membawa dampak pada perubahan kinerja guru. Suherman menjelaskan beberapa faktor yang mempengaruhi motivasi kerja guru yang dapat diungkap, yaitu:

a. Kepribadian dan dedikasi

Setiap guru memiliki pribadi masing-masing sesuai ciri-ciri pribadi mereka miliki. Ciri-ciri inilah yang membedakan seorang guru dari guru lainnya. Kepribadian sebenarnya adalah suatu masalah abstrak, hal ini dipertegas Darajat bahwa kepribadian 
yang sesungguhnya adalah abstrak, sukar dilihat atau diketahui secara nyata, yang dapat diketahui adalah penampilan atau bekasnya dalam segala segi dan aspek kehidupan, misalnya dalam tindakan, ucapan, caranya bergaul, berpakaian, dan dalam menghadapi setiap persoalan atau masalah, baik yang ringan maupun yang berat. (Zakiah Daradjat, 2005: 106).

Kepribadian guru akan tercermin dalam sikap dan perbuatannya dalam membina dan membimbing peserta didik. Semakin baik kepribadian seorang guru diharapkan semakin baik pula dedikasinya dalam menjalankan tugas dan tanggung jawabnya sebagai guru, ini berarti tercermin suatu dedikasi yang tinggi dari guru dalam melaksanakan tugas dan fungsinya sebagai pendidik.

Aspek-aspek tersebut merupakan kompetensi kepribadian sebagai syarat mutlak yang harus dimiliki oleh seorang guru dalam melaksanakan profesinya. Karena tanpa aspek tersebut sulit bagi guru untuk dapat melaksanakan tugas sesuai dengan harapan. Kepribadian dan dedikasi yang tinggi dapat meningkatkan kesadaran akan pekerjaan dan mampu menunjukkan kinerja yang memuaskan seseorang atau kelompok dalam suatu organisasi. Guru yang memiliki kepribadian yang baik dapat membangkitkan keamauan untuk giat memajukan profesinya dan meningkatkan dedikasi dalam melakukan pekerjaan mendidik sehingga dapat dikatakan guru tersebut memiliki komitmen yang baik dalam menjalankan profesinya.

\section{b. Pengembangan Profesi}

Profesi guru kian hari menjadi perhatian seiring dengan perubahan ilmu pengetahuan dan teknologi yang menuntut kesiapan agar tidak ketinggalan. Menurut Pidarta bahwa profesi ialah suatu jabatan atau pekerjaan biasa seperti halnya dengan pekerjaan-pekerjaan lain, tetapi pekerjaan itu harus diterapkan pada masyarakat untuk kepentingan masyarakat umum, bukan untuk kepentingan individual, kelompok, atau golongan tertentu (M. Pidarta, 2008: 112).

Pengembangan profesionalisme guru menekankan kepada penguasaan ilmu pengetahuan atau kemampuan manajemen beserta strategi penerapannya. Tuntutan memenuhi standar profesionalisme bagi guru sebagai wujud dari keinginan menghasilkan guru yang mampu membina peserta didik sesuai dengan tuntutan masyarakat, disamping sebagai tuntutan yang harus dipenuhi guru dalam meraih predikat guru yang profesional sebagaimana yang dijelaskan dalam Educational Leadership dalam Supriadi bahwa untuk menjadi profesional, seorang guru dituntut untuk memiliki lima hal, yaitu:

1) Guru harus mempunyai komitmen,

2) Guru menguasai secara mendalam bahan/materi mata pelajaran yang diajarkannya serta cara mengajarnya kepada peserta didik,

3) Guru bertanggung jawab memantau hasil belajar peserta didik melalui berbagai cara evaluasi,

4) Guru mampu berpikir sistematis tentang apa yang dilakukannya dan belajar dari 
pengalamannya,

5) Guru seyogyanya merupakan bagian dari masyarakat belajar dalam lingkungan profesinya. (Supriadi, 1999: 42).

Menyadari akan profesi merupakan wujud eksistensi guru sebagai komponen yang bertanggung jawab dalam keberhasilan pendidikan maka menjadi satu tuntutan bahwa guru harus sadar akan peran dan fungsinya sebagai pendidik.

Makin tinggi kesadaran seseorang makin kuat keinginannya meningkatkan profesi, artinya semakin sering profesi guru dikembangkan melalui berbagai kegiatan maka semakin mendekatkan guru pada pencapaian predikat guru yang profesional dalam menjalankan tugasnya sehingga harapan kinerja guru yang lebih baik akan tercapai.

\section{Komunikasi}

Kegiatan pembelajaran yang dilakukan guru akan berhasil jika ada hubungan dan komunikasi dengan komponen yang diajar. Kinerja guru akan meningkat seiring adanya kondisi hubungan yang sehat di antara kedua komponen tersebut sebab dengan pola hubungan dan komunikasi yang lancar dan baik mendorong pribadi seseorang untuk melakukan tugas dengan baik (Pidarta:17).

Terbinanya hubungan dan komunikasi di dalam lingkungan madrasah memungkinkan guru dapat mengembangkan kreativitasnya sebab ada jalan terjadinya interaksi dan ada respon balik dari komponen lain di madrasah atas kreativitas dan inovasi tersebut. Hal ini menjadi motor penggerak bagi guru untuk terus meningkatkan daya inovasi dan kreativitasnya. Ini berarti bahwa pembinaan hubungan dan komunikasi yang baik di antara komponen dalam madrasah menjadi suatu keharusan dalam menunjang peningkatan kinerja. Untuk itu, semakin baik pembinaan hubungan dan komunikasi dibina maka respon yang muncul semakin baik pula yang pada gilirannya mendorong peningkatan kinerja.

\section{Hubungan dengan masyarakat}

Hubungan guru dengan masyarakat perlu terjamin baik dan berlangsung secara kontinu, oleh karenanya diperlukan peningkatan profesi guru dalam hal berhubungan dengan masyarakat. Guru disamping mampu melakukan tugasnya di sekolah/madrasah, mereka juga diharapkan dapat dan mampu melakukan tugas-tugas hubungan dengan masyarakat. Untuk mencapai hal itu diperlukan kompetensi dan perilaku dari guru yang cocok dengan struktur sosial masyarakat setempat, sebab ketika kompetensi dan perilaku guru tidak cocok dengan struktur sosial dalam masyarakat maka akan terjadi benturan pemahaman dan salah pengertian terhadap program yang dilaksanakan madrasah dan berakibat tidak adanya dukungan masyarakat terhadap madrasah, padahal madrasah dan masyarakat memiliki kepentingan yang sama dan peran yang strategis dalam mendidik dan menghasilkan peserta didik yang berkualitas. Kemampuan guru 
membawa diri, baik di sekolah maupun di tengah masyarakat dapat mempengaruhi penilaian masyarakat terhadap guru. Guru harus bersikap sesuai dengan norma-norma yang berlaku di masyarakat, responsif dan komunikatif terhadap masyarakat, toleran dan menghargai pendapat mereka

\section{Kedisiplinan}

Kedisiplinan guru sangat perlu dalam menjalankan tugas dan kewajibannya sebagai pengajar, pendidik, dan pembimbing peserta didik. Kedisiplinan bagi guru merupakan bagian yang tidak terpisahkan dengan tugas dan kewajibannya.

Dengan demikian, kedisiplinan seorang guru menjadi tuntutan yang sangat penting untuk dimiliki dalam upaya menunjang dan meningkatkan kinerja dan di sisi lain akan memberikan teladan bagi peserta didik bahwa disiplin sangat penting bagi siapapun apabila ingin sukses.

\section{Kompetensi Profesional Guru}

Kompetensi guru adalah salah satu faktor yang mempengaruhi tercapainya tujuan pembelajaran dan pendidikan di sekolah/madrasah karena kompetensi guru pada hakikatnya tidak bisa dilepaskan dari konsep hakikat guru dan hakikat tugas guru. Kompetensi guru mencerminkan tugas dan kewajiban guru yang harus dilakukan sehubungan dengan tugas jabatan guru.

Dalam Peraturan Pemerintah RI Nomor 19/2005 tentang Standar Nasional Pendidikan dikemukakan bahwa pendidikan harus memiliki kualifikasi akademik dan kompetensi sebagai agen pembelajaran, sehat jasmani dan rohani, serta memiliki kemampuan untuk mewujudkan tujuan pendidikan nasional. (Peraturan Pemerintah RI Nomor 19/2005, Pasal 28).

Sehubungan dengan pernyataan di atas, guru atau pendidik sebagai agen pembelajaran maka guru harus memiliki empat jenis kompetensi, yakni kompetensi pedagogik, kepribadian, profesional, dan sosial. Dalam konteks itu maka kompetensi guru dapat diartikan sebagai kebulatan pengetahuan, keterampilan dan sikap yang diwujudkan dalam bentuk perangkat tindakan cerdas dan penuh tanggung jawab. Keempat jenis kompetensi guru yang dipersyaratkan beserta subkompetensi dan indikator essensialnya diuraikan sebagai berikut:

a. Kompetensi pedagogik

Dalam penjelasan Peraturan Pemerintah RI Nomor 19 tahun 2005 tentang Standar Nasional Pendidikan dikemukakan bahwa kompetensi pedagogik adalah kemampuan mengelola pembelajaran peserta didik yang meliputi pemahaman terhadap peserta didik, perancangan dan pelaksanaan pembelajaran, evaluasi hasil belajar dan pengembangan peserta didik untuk mengaktualisasikan berbagai potensi yang dimilikinya. (Departemen Agama: 230). Secara subtantif kompetensi ini mencakup hal-hal berikut: (1) memahami peserta didik dengan memanfaatkan prinsip-prinsip perkembangan kognitif, dan prinsip 
kepribadian. (2) merancang pembelajaran, (3) melaksanakan pembelajaran yang kondusif. (4) merancang dan melaksanakan evaluasi (assesement) proses dan hasil belajar secara berkesinambungan, (5) mengembangkan peserta didik untuk mengaktualisasikan berbagai potensi; memfasilitasi peserta didik untuk pengembangan berbagai potensi akademik dan potensi non akademik (Oemar Hamalik: 104).

b. Kompetensi kepribadian

Kompetensi kepribadian merupakan kemampuan personal yang mencerminkan kepribadian yang mantap, stabil, dewasa, arif, dan berwibawa, menjadi teladan bagi peserta didik dan berakhlak mulia (Departemen Agama: 230). Pribadi guru memiliki andil yang sangat besar terhadap keberhasilan pendidikan, khususnya dalam kegiatan pembelajaran. Pribadi guru juga sangat berperan dalam membentuk pribadi peserta didik, karena manusia merupakan mahluk yang suka mencontoh termasuk mencontoh pribadi gurunya dalam membentuk pribadi peserta didik. Guru yang memiliki kinerja yang baik tentunya memiliki komitmen yang tinggi dalam pribadinya, artinya tercermin suatu kepribadian dan dedikasi yang paripurna.

c. Kompetensi Sosial

Kompetensi sosial berkenaan dengan kemampuan pendidik sebagai bagian dari masyarakat untuk berkomunikasi dan bergaul secara efektif dengan peserta didik, sesama pendidik, tenaga kependidikan, orang tua/wali peserta didik, dan masyarakat sekitar (Departemen Agama: 230). Kompetensi ini memiliki subkompetensi dengan indikator esensial yaitu: (1) mampu berkomunikasi dan bergaul sesama secara efektif dengan peserta didik, (2) mampu berkomunkasi dan bergaul sesama pendidik dan tenaga kependidikan, dan (3) mampu berkomunkasi dan bergaul secara efektif dengan orang tua/wali peserta didik dan masyarakat sekitar (Oemar Hamalik: 115). Guru adalah makhluk sosial, yang dalam kehidupannya tidak bisa terlepas dari kehidupan sosial masyarakat dan lingkungannya. Guru dalam menjalani kehidupan seringkali menjadi tokoh panutan, dan identifikasi bagi peserta didik dan lingkungannya. Ashraf mengungkapkan bahwa Imam Al-Gazali menempatkan profesi guru pada posisi tertinggi dan termulia dalam berbagai tingkat pekerjaan masyarakat (Ali Ashraf: 226).

d. Kompetensi Profesional.

Dalam penjelasan Peraturan Pemerintah RI Nomor 19 tahun 2005 tentang Standar Nasional Pendidikan, dikemukakan bahwa yang dimaksud dengan kompetensi profesional adalah kemampuan penguasaan materi pembelajaran secara luas dan mendalam yang memungkinkannya membimbing peserta didik memenuhi standar kompetensi yang ditetapkan dalam Standar Nasional Pendidikan. (Departemen Agama: 230).

Memahami uraian di atas, tampak bahwa kompetensi profesional merupakan kompetensi yang harus dikuasai guru dalam kaitannya dengan pelaksanaan tugas utama guru di sekolah/madrasah, beberapa hal penting yang harus dimiliki guru adalah 
kemampuan menjabarkan materi standar dalam kurikulum. Untuk kepentingan tersebut guru harus mampu menentukan secara tepat materi yang relevan dengan kebutuhan dan kemampuan peserta didik.

\section{METODOLOGI PENELITIAN}

Penelitian ini tergolong sebagai penelitian survei yang dilaksanakan di seluruh Madrasah Tsanawiyah dalam lingkungan Kementerian Agama Kota Makassar yang terdiri atas 2 Madrasah Tsanawiyah Negeri dan 32 Madrasah Tsanawiyah Swasta. Populasi guru dari 34 Madrasah Tsanawiyah di Kota Makassar adalah 729 orang. Pengambilan sampel penelitian ini dilakukan dengan menggunakan teknik Proportionate Stratified Random Sampling berdasarkan pada tabel penentuan jumlah sampel dari populasi yang dikembangkan dari Isaac dan Michael.

Pengumpulan data dalam penelitian ini menggunakan observasi, interview (wawancara), angket atau kuesioner, dan dokumentasi. Untuk memperoleh data dari variabel-variabel dalam penelitian ini digunakan instrumen berupa kuesioner untuk mengukur komitmen profesi guru dan untuk mengukur kompetensi profesional guru. Setiap kuesioner terdapat lima alternatif jawaban. Skor jawaban dari lima alternatif bergerak dari skor 5 sampai dengan 1 . Untuk pernyataan positif jawaban a. Skor 5, b. Skor 4, c. Skor 3, d. Skor 2, dan e. Skor 1 dan pernyataan negatif sebaliknya. Disamping instrumen tersebut digunakan juga pedoman wawancara, field note, dan pedoman observasi sebagai instrumen pendukung. Sebelum digunakan, instrumen tersebut di atas terlebih dahulu diadakan uji validitas dan realibitas yang dilaksanakan sebanyak 2 kali. Tahap pertama, uji instrumen di berikan pada 30 orang guru Madrasah Tsanawiyah Negeri Model Makassar, tetapi karena responden homogen maka item istrumen banyak yang tidak valid. Tahap kedua, uji instrumen diberikan pada 30 orang guru Madrasah Negeri dan Swasta.

Teknik pengolahan data yang ditempuh yaitu: (a) mereduksi data, (b) menyajikan data, dan (c) menarik kesimpulan. Analisis data menggunakan teknik statistik, baik statistik deskriptif maupun statistik inferensial. Untuk keperluan analisis statistik inferensial digunakan paket program komputer yaitu SPSS versi.17.

\section{HASIL PENELITIAN DAN PEMBAHASAN}

\section{Hasil Penelitian}

\section{Komitmen Profesi Guru Madrasah Tsanawiyah di Kota Makassar}

Secara umum komitmen profesi guru madarasah Tsanawiyah di Kota Makassar, dari 195 responden, yang menyatakan sangat sering sebanyak 30,04 persen, sering sebanyak 30,34 persen, kadang-kadang sebanyak 31,84 persen, jarang sebanyak 6,03 persen, dan tidak pernah sebanyak 1,74 persen. Hal ini menggambarkan bahwa guru madrasah Tsanawiyah di Kota Makassar telah memiliki komitmen profesi yang baik tetapi persentase yang terbanyak berada pada kategori sedang. Ini berarti guru madrasah Tsanawiyah di Kota Makassar dalam mengenali profesi, keterikatan dan keterlibatan, 
rasa memiliki, kesetiaan, dan kebanggaan terhadap profesi berada pada kategori sedang.

\section{Kompetensi Profesional Guru Madrasah Tsanawiyah di Kota Makassar}

Secara umum kompetensi profesional guru Madrasah Tsanawiyah di Kota Makassar, dari 195 responden yang rata-rata menyatakan sangat sering sebanyak 28,06 persen, sering sebanyak 31,78 persen, kadang-kadang sebanyak 34,33 persen, jarang sebanyak 4,38 persen, dan tidak pernah sebanyak 1,44 persen. Hal ini menggambarkan bahwa guru madrasah Tsanawiyah di Kota Makassar telah melaksanakan kompetensi profesional dengan baik tetapi persentase terbanyak berada pada kategori sedang. Artinya bahwa guru madrasah Tsanawiyah dalam hal: 1) Penguasaan materi, Struktur, konsep, dan pola keilmuan yang mendukung mata pelajaran yang diampu, 2) Penguasaan Standar Kompetensi (SK) dan Kompetensi Dasar (KD), 3) Pengembangan materi pembelajaran yang diampu secara kreatif, serta 4) Pengembangan keprofesionalan secara berkelanjutan dengan melakukan tindakan reflektif, berada pada kategori sedang.

\section{Pengaruh Komitmen Profesi terhadap Kompetensi Profesional Guru Madrasah Tsanawiyah di Kota Makassar}

Hipotesis yang dirumuskan adalah: Komitmen profesi berpengaruh positif terhadap kompetensi profesional guru Madrasah Tsanawiyah di Kota Makassar. Untuk keperluan pengujian hipotesis di atas, maka hipotesis tersebut ditampilkan secara statistik sebagai berikut:

Ho : $\beta 1=0$

$\mathrm{H}_{1}: \beta 1>0$

Kriteria pengujian:

- Ho diterima, bila probabilitas (p) $>\alpha(0.05)$ taraf kepercayaan 95\%, dengan demikian tidak ada pengaruh positif antar variabel, sedangkan

- H1 diterima, bila probabilitas $(\mathrm{p})<\alpha(0.05)$ taraf kepercayaan 95\%, dengan demikian ada pengaruh positif antar variabel.

Pada penelitian ini dilakukan beberapa uji asumsi klasik terhadap model regresi linier sederhana yaitu Uji Normalitas, Uji Heterokedastisitas, dan Uji Autokorelasi yang telah diolah dengan menggunakan program SPSS versi 17 sebagai berikut: Berdasarkan hasil pengolahan data maka didapatkan hasil bahwa semua data berdistribusi secara normal dan tidak terjadi penyimpangan, sehingga data yang dikumpulkan dapat diproses dengan metode-metode selanjutnya. Hal ini dapat dibuktikan dengan memperhatikan tabel uji Kolmogorov-Smirnov dimana terlihat bahwa data dapat dikatakan berdistribusi normal apabila nilai Asymp. Sig. (2-tailed) 0,000 maka data dikatakan berdistribusi Normal sehingga data yang dikumpulkan dapat diproses dengan metode-metode selanjutnya.

Dari hasil output SPSS dengan menggunakan metode grafik terlihat bahwa titik- 
titik hasil scatterplot dari variabel terikat tidak membentuk pola-pola tertentu atau menyebar dengan sempurna. Maka dapat dikatakan bahwa data memenuhi asumsi Heterokedastisitas dan dapat dilakukan analisis dengan metode-metode selanjutnya.

Setelah terpenuhinya asumsi analisis regresi, maka dapat dilihat hasil analisis regresi. Dari hasil pengolahan menggunakan program SPSS versi 17.0 didapatkan hasil tabel model persamaan regresi.

Dari persamaan regresi dapat diketahui: Hasil penelitian terlihat bahwa nilai $t$ statistik untuk variabel Kompetensi Profesional (X) sebesar 0,995 dan signifikan pada alfa 5\% karena p-value $\mathrm{t}$ statistik sebesar 0,000 yang signifikan dipengaruhi variabel Komitmen Profesi (Y).

Dengan demikian, dapat dilihat bahwa komitmen profesi cukup berpengaruh terhadap kompetensi profesional yaitu dengan koefisien regresi sebesar 0,995 artinya apabila terjadi peningkatan terhadap komitmen profesi satu satuan maka akan terjadi peningkatan pada kompetensi profesional sebesar 0,995. Jadi dapat disimpulkan bahwa faktor komitmen profesi sangat penting dalam menentukan kompetensi profesional.

Untuk memvalidasi model regresi ini, perlu dilakukan pemeriksaan nilai $\mathrm{F}$ pada tabel diatas, dari hasil uji statistik F menunjukkan nilai p-value sebesar 0,05 dan nilai koefisien determinasi ( $\mathrm{R}$ square) pada tabel diatas sebesar 0,813 dengan kata lain 81,3\% variability variabel kompetensi profesional mampu dijelaskan oleh variabel komitmen profesi sedangkan sisanya $18,7 \%$ dijelaskan oleh variabel lainnya. Oleh karena nilai statistik uji $\mathrm{F}$ yang signifikan pada alfa 5\% dan nilai R square yang tinggi, maka model persamaan regresi yang dihasilkan dapat dikatakan valid.

\section{Pembahasan}

Bertolak dari teori dan hasil-hasil penelitian yang diperoleh maka pada bagian ini dikemukakan pembahasan hasil penelitian sebagai berikut:

\section{Komitmen Profesi Guru Madrasah Tsanawiyah di Kota Makassar}

Berdasarkan hasil analisis deskripsi tentang komitmen profesi guru, setelah diolah dan dianalisis dalam bentuk tabel frekuensi dan persentase masing-masing item dalam angket yang terdiri atas 41 item maka dapat diperoleh gambaran tingkat komitmen guru Madrasah Tsanawiyah di Kota Makassar. Hasil analisis dari keseluruhan item atau butir-butir pertanyaan dalam angket menunjukkan bahwa tingkat komitmen profesi guru madrasah Tsanawiyah di Kota Makassar berada pada kategori kadang atau sedang. Ini berarti bahwa komitmen profesi guru Madrasah Tsanawiyah belum maksimal dalam menjalankan tugas dan fungsinya sebagai pendidik yang profesional. Ini dikarenakan beberapa hal yang mempengaruhi komitmen profesi guru yaitu; motivasi, komunikasi, sertifikasi, fungsi kepala madrasah, fungsi pengawas pendidikan, akan dibahas berikut ini: 


\section{a. Motivasi}

Motivasi dibutuhkan oleh banyak orang untuk memacu baik diri sendiri maupun orang lain untuk lebih baik dalam mengerjakan sesuatu. Motivasi adalah dorongan psikologis yang mengarahkan seseorang ke arah suatu tujuan. Motivasi membuat keadaan dalam individu muncul, terarah, dan mempertahankan perilaku.

Motivasi kerja adalah suatu dorongan jiwa yang membuat seseorang tergerak untuk melakukan tindakan yang produktif, baik yang berorientasi kerja mengharap-kan reward maupun yang tidak. Motivasi kerja yang dimiliki seseorang berbeda-beda, dan juga berfluktuasi.

Profesi guru adalah tugas mulia yang harus dijalankan dengan penuh tanggung jawab, guru yang memiliki sifat rabbani, tentu memiliki semangat kerja dan prestasi kerja yang tinggi atau kinerja yang tinggi. Maksudnya seorang guru dalam menjalankan aktivitas pendidikan bukan semata-mata untuk memperluas wawasan keilmuannya saja, tetapi menuntut keridaan Allah swt. dalam mewujudkan kebenaran. Kebenaran ini menjadi keharusan bagi guru untuk menanamkan dan menyebarluaskan kepada peserta didiknya dengan penuh keikhlasan.

Pentingnya motivasi dalam bekerja sudah merupakan kebutuhan dalam meningkatkan kinerja seperti pada; Kebutuhan akan prestasi, kebutuhan ini merupakan dorongan untuk mengungguli, berprestasi sehubungan dengan kompetisi dalam meraih sukses. Kebutuhan ini pada hirarki menurut Maslow terletak antara kebutuhan akan penghargaan dan kebutuhan akan aktualisasi diri.

Selain motivasi internal yaitu motivasi dari dalam diri, dari perasaan dan pikiran diri sendiri, juga dikenal dengan motivasi eksternal yaitu motivasi dari luar atau mendapatkan rangsangan dari luar. Hal ini sebenarnya sangat diperlukan bagi orang yang kurang memiliki motivasi internal, tetapi inipun belum berjalan sebagaimana seharusnya. Kepala sekolah sebagai atasan juga pimpinan secara kelembagaan ataupun pengawas pendidikan dalam lingkungan binaannya belum optimal dalam memberikan reward terhadap guru yang memiliki prestasi. Sehingga guru kurang memiliki semangat dalam berkompetisi dan cenderung melaksanakan tugas seperti apa adanya.

\section{b. Komunikasi}

Pada umumnya, komunikasi dilakukan dengan menggunakan kata-kata yang dapat dimengerti oleh kedua belah pihak. Melalui komunikasi, sikap dan perasaan seseorang atau sekelompok orang dapat dipahami oleh pihak lain. Selain itu dalam kehidupan sehari-hari, komunikasi yang baik sangat penting untuk berinteraksi antar personal maupun antar masyarakat agar terjadi keserasian dan mencegah konflik dalam lingkungan masyarakat. Dalam lingkungan sekolah/madrasah juga sangat diperlukan komunikasi agar hubungan tersebut dapat berjalan dengan baik dan lancar, seperti hubungan guru dengan peserta didik, dengan adanya komunikasi maka kegiatan pembelajaran akan berlangsung sebagaimana yang diharapkan, demikian pula komunikasi guru dengan guru lainnya dan seluruh warga sekolah/madrasah. 
Tugas guru yang diemban timbul dari rasa percaya masyarakat terdiri dari mentransfer kebudayaan dalam arti yang luas, keterampilan menjalani kehidupan (Life skills), terlibat dalam kegiatan-kegiatan menjelaskan, mendefinisikan, membuktikan dan mengklasifikasi-kan, selain harus menunjukkan sebagai orang yang berpengetahuan luas, trampil dan sikap yang bisa dijadikan panutan. Maka dari itu, guru harus memiliki kemampuan berkomunikasi dalam membimbing peserta didik untuk siap menghadapi kehidupan yang sebenarnya (the real life) dan bahkan mampu memberikan keteladanan yang baik.

\section{c. Sertifikasi}

Gagasan awal sertifikasi adalah untuk meningkatkan mutu pendidikan secara keseluruhan. Sesuai amanat UU Nomor 14 tahun 2004 tentang Guru dan Dosen yang menetapkan kualifikasi, kompetensi, dan sertifikasi sebagai suatu kesatuan upaya pemberdayaan guru. Maka program ini hendaknya janganlah dipandang sebagai proses legalisasi semata, akan tetapi harus dipandang sebagai ijtihad untuk meningkatkan kompetensi profesi guru, karena itu proses ini harus betul-betul dilakukan secara teliti dan cermat agar tak menurunkan mutu guru.

Dalam Permendiknas Nomor 18 tahun 2007 tentang Sertifikasi bagi Guru dalam Jabatan disebutkan bahwa sertifikasi bagi guru dalam jabatan dilaksanakan melalui uji kompetensi dalam bentuk penilaian portofolio alias penilaian kumpulan dokumen yang mencerminkan kompetensi guru, dengan mencakup 10 (sepuluh) komponen yaitu : (1) kualifikasi akademik, (2) pendidikan dan pelatihan, (3) pengalaman mengajar, (4) perencanaan dan pelaksanaan pembelajaran, (5) penilaian dari atasan dan pengawas, (6) prestasi akademik, (7) karya pengembangan profesi, (8) keikutsertaan dalam forum ilmiah, (9) pengalaman organisasi di bidang pendidikan dan pengajaran, dan (10) penghargaan yang relevan dengan bidang pendidikan.

Jika kesepuluh komponen tersebut telah dapat terpenuhi secara obyektif dengan mencapai skor minimal 850 atau 57\% dari perkiraan skor maksimum (1500), maka guru yang bersangkutan bisa dipastikan untuk berhak menyandang predikat sebagai guru profesional, beserta sejumlah hak dan fasilitas yang melekat dengan jabatannya. Sayangnya, untuk memenuhi batas minimal 57\% saja ternyata tidak semudah yang dibayangkan.

Permasalahan tidak hanya dirasakan oleh guru yang belum memiliki kualifikasi S1, tetapi bagi guru yang sudah berkualifikasi S1 pun tetap akan menjumpai sejumlah persoalan, terutama kesulitan guna memenuhi empat komponen lainnya, yaitu komponen: (1) pendidikan dan pelatihan, (2) keikutsertaan dalam forum ilmiah, (3) prestasi akademik, dan (4) karya pengembangan profesi.

Dari sisi personal, guru yang sudah tersertifikasi seyogyanya dapat menunjukkan keteladanan pribadi, menjadi panutan bagi guru yang lainnya. Sementara dari segi sosial, diharapkan dapat menunjukkan sosiabilitas yang tinggi dan memiliki nilai manfaat lebih bagi lingkungan sosialnya, khususnya bagi para rekan sejawat. Dari sisi 
pedagogik, guru yang sudah tersertifikasi seyogyanya dapat menunjukkan kemampuan pedagogiknya terutama pada saat menjalankan proses pembelajaran peserta didik. Dari guru yang sudah tersertifikasi diharapkan dapat muncul berbagai inovasi pembelajaran yang dapat dimanfaatkan dan diterapkan paling tidak di lingkungan sekolah/madrasahnya. Dari sisi akademik, pendalaman tentang substansi materi dari mata pelajaran yang diampunya, diharapkan muncul karya-karya tulis yang bermutu untuk disharingkan dengan rekan sejawat lainnya.

\section{d. Peran Kepala Madrasah}

Kepemimpinan kepala madrasah sangat berperan dalam meningkatkan komitmen profesi guru dalam melaksanakan tugas di madrasah. Tinggi rendahnya disiplin kerja guru banyak dipengaruhi oleh kepemimpinan kepala sekolah. Kepala sekolah bertangggung jawab melaksanakan fungsi-fungsi kepemimpinan baik yang berhubungan dengan pencapaian tujuan pendidikan maupun dalam menciptakan iklim sekolah/madrasah yang kondusif serta menumbuhkan motivasi tenaga pendidik maupun peserta didik. Dengan kepemimpinan kepala sekolah inilah, diharapkan dapat memberikan dorongan serta memberikan kemudahan untuk kemajuan serta dapat memberikan inspirasi dalam proses pencapaian tujuan.

Kepala madrasah yang merupakan pemimpin pendidikan tertinggi di madrasah diharapkan bertanggung jawab dalam peningkatan komitmen profesi guru dan ini perlu dilaksanakan secara berkesinambungan. Peran kepala madrasah dalam upaya peningkatan komitmen profesi guru sangat besar untuk membangkitkan semangat guru dalam mengabdi yang akan melahirkan visi kelembagaan maupun kemampuan konsepsional yang jelas. Dan ini merupakan faktor yang paling penting sebab tanpa adanya kesadaran dan motivasi semangat mengabdi inilah semua usaha yang dilakukan untuk meningkatkan profesionalisme guru hasilnya tidak akan maksimal.

\section{e. Peran Pengawas Pendidikan}

Pengawas sekolah/madrasah adalah Pegawai Negeri Sipil yang diberi tugas, tanggung jawab, dan wewenang secara penuh oleh pejabat yang berwenang untuk melakukan pengawasan pendidikan di sekolah/madrasah dengan melaksanakan penilaian dan pembinaan dari segi teknis pendidikan dan administrasi pada satuan pendidikan.

Oleh karena itu, pengawas pendidikan haruslah memahami konsep pem-binaan, jenis-jenis pembinaan, strategi pembinaan, komunikasi dalam membina, hubungan antarpersonal dalam membina, dan sebagainya. Sekaitan dengan tugas pembinaan, pengawas pendidikan juga harus piawai dalam merencanakan, melaksanakan, menilai hasil pembinaan, dan menindaklanjuti hasilnya.

Pada umumnya guru Madrasah Tsanawiyah di Kota Makassar senantiasa menantikan pembinaan yang intensif dari pengawas pendidikan, demikian juga pengawas pendidikan di Kota Makassar menyadari pentingnya pembinaan terhadap guru. Pandangan pengawas terhadap komitmen kerja guru Madrasah Tsanawiyah di 
Kota Makassar dalam kategori sedang dan masih perlu di motivasi sehingga guru memiliki tingkatan komitmen yang tinggi dalam melaksanakan tugas karena merasa adanya suatu kewajiban atau tanggung jawab.

\section{Kompetensi Profesional Guru Madrasah Tsanawiyah di Kota Makassar}

Berdasarkan hasil analisis deskriptif data tentang kompetensi profesional guru, setelah diolah dan dianalisis dalam bentuk tabel frekuensi dan persentase masingmasing item dalam angket yang terdiri atas 40 item maka dapat diperoleh gambaran kompetensi profesional guru Madrasah Tsanawiyah di Kota Makassar. Hasil analisis dari keseluruhan item atau butir-butir pertanyaan dalam angket menunjukkan bahwa kompetensi profesional guru Madrasah Tsanawiyah di Kota Makassar berada pada kategori sedang. Ini berarti bahwa guru madrasah Tsanawiyah belum maksimal dalam menjalankan tugas dan fungsinya dalam proses pembelajaran. Ini dikarenakan beberapa hal yang terkait dengan kompetensi profesional guru akan dibahas berikut ini:

a. Penguasaan materi, struktur, konsep, dan pola keilmuan yang mendukung mata pelajaran yang diampu

Hasil analisis deskriptif data tentang kompetensi profesional guru dalam hal penguasaan materi, struktur, konsep, dan pola keilmuan yang mendukung mata pelajaran yang diampu, setelah diolah dan dianalisis dalam bentuk tabel frekuensi dan persentase masing-masing item dalam angket yang terdiri atas 11 item yaitu pada tabel 53 s/d 63, maka dapat diperoleh gambaran kompetensi profesional guru Madrasah Tsanawiyah di Kota Makassar berada pada kategori kadang-kadang atau sedang.

Penguasaan materi, struktur, konsep, dan pola keilmuan yang mendukung mata pelajaran yang diampu ini meliputi; Kompetensi profesional guru dalam hal mempelajari terlebih dahulu materi pelajaran sebelum diajarkan, menyampaikan tujuan pembelajaran pada awal kegiatan inti, menerapkan keterampilan membuka pelajaran untuk membangkitkan motivasi belajar, proses pembelajaran menerapkan multi metode disesuaikan dengan kebutuhan materi pelajaran, memberikan solusi terhadap permasalahan yang dikemukakan peserta didik, berupaya menciptakan suasana, iklim, dan lingkungan pembelajaran yang kondusif, berusaha agar semua peserta didik mendapat giliran dalam menjawab pertanyaan guna menumbuhkan rasa percaya diri peserta didik, memberi kesempatan peserta didik bertanya pada saat menjelaskan materi pelajaran, membahas materi pelajaran dengan tuntas, melaksanakan tindak lanjut dari hasil evaluasi dalam bentuk remedial dan pengayaan, serta mendokumentasikan hasil evaluasi yang telah dilaksanakan.

b. Penguasaan Standar Kompetensi (SK) dan Kompetensi Dasar (KD)

Hasil analisis deskriptif data tentang kompetensi profesional guru dalam hal penguasaan Standar Kompetensi (SK) dan Kompetensi Dasar (KD) mata pelajaran yang diampu, setelah diolah dan dianalisis dalam bentuk tabel frekuensi dan persentase masing-masing item dalam angket yang terdiri atas 10 item yaitu pada tabel $64 \mathrm{~s} / \mathrm{d} 73$, 
maka dapat diperoleh gambaran kompetensi profesional guru Madrasah Tsanawiyah di Kota Makassar berada pada kategori kadang atau sedang.

Standar Kompetensi (SK) dan Kompetensi Dasar (KD) menjadi arah dan landasan untuk mengembangkan materi pokok, kegiatan pembelajaran, dan proses pencapaian kompetensi untuk penilaian. Guru dalam merancang kegiatan pembelajaran dan penilaian perlu memperhatikan Standar Proses dan Standar Penilaian.

Penjabaran standar kompetensi dan kompetensi dasar sebagai bagian dari pengembangan Kurikulum Tingkat Satuan Pendidikan (KTSP) dilakukan melalui pengembangan silabus dan rencana pelaksanaan pembelajaran.

Dalam Peraturan Pemerintah nomor 19 tahun 2005 pasal 20, diisyaratkan bahwa guru diharapkan mengembangkan materi pembelajaran, yang kemudian dipertegas malalui Peraturan Menteri Pendidikan Nasional (Permendiknas) nomor 41 tahun 2007 tentang Standar Proses, yang antara lain mengatur tentang perencanaan proses pembelajaran yang mensyaratkan bagi pendidik pada satuan pendidikan untuk mengembangkan rencana pelaksanaan pembelajaran (RPP). Salah satu elemen dalam RPP adalah sumber belajar. Dengan demikian, guru diharapkan untuk mengembangkan materi pembelajaran sebagai salah satu sumber belajar dan acuan pembelajaran

Memahami Standar Kompetensi dan Kompetensi Dasar Mata Pelajaran ini meliputi: Kompetensi profesional guru dalam menyusun Rencana Pelaksanaan Pembelajaran (RPP) yang dijabarkan dalam Silabus, menjabarkan Standar Kompetensi (SK) dan Kompetensi dasar (KD) ke dalam indikator-indikator untuk setiap sub pokok bahasan, merancang metode pembelajaran sesuai dengan tujuan pembelajaran, menyusun rencana pembelajaran secara runtut dan sistematis sesuai dengan alokasi waktu, membuat penilaian hasil belajar sesuai dengan kompetensi dasar, menyiapkan kelengkapan instrumen evaluasi (soal, kunci, dan pedoman penskoran), menginformasikan kepada peserta didik rancangan dan kriteria penilaian yang ada dalam silabus mata pelajaran, menutup pembelajaran, membuat kesimpulan dan penekanan terhadap tujuan pembelajaran tersebut, menyusun rencana tindak lanjut hasil evaluasi, menyusun strategi pembelajaran untuk memudahkan peserta didik memahami materi pelajaran.

c. Pengembangan materi pembelajaran yang diampu secara kreatif

Hasil analisis deskriptif data tentang kompetensi profesional guru dalam hal pengembangan materi pembelajaran yang diampu secara kreatif, setelah diolah dan dianalisis dalam bentuk tabel frekuensi dan persentase masing-masing item dalam angket yang terdiri atas 9 item yaitu pada tabel $74 \mathrm{~s} / \mathrm{d}$ 82, maka dapat diperoleh gambaran kompetensi profesional guru madrasah Tsanawiyah di Kota Makassar berada pada kategori kadang atau sedang.

Tugas guru tidak hanya sekedar transfer of knowlege atau menyampaikan informasi kepada peserta didik, tetapi harus menjadi fasilitator, motivator, inspirator, dan inovator yang dapat membolduser siswa yang mendobrak diri untuk maju. Hal ini 
sejalan amanat dari Peraturan Pemerintah nomor 19 tahun 2005 tentang Standar Nasional Pendidikan pada pasal 19, yaitu bahwa proses pembelajaran pada satuan pendidikan diselenggarakan secara interaktif, inspiratif, menyenangkan, menantang, memotivasi peserta didik untuk berpartisipasi aktif, serta memberikan ruang yang cukup bagi prakarsa, kreatifitas, dan kemandirian sesuai bakat, minat, dan perkembangan fisik serta psikologis peserta didik.

Prinsip-prinsip dalam mengembangkan materi pembelajaran meliputi: (a) prinsip relevansi, (b) konsistensi, dan (c) kecukupan. Prinsip relevansi artinya materi pembelajaran hendaknya memiliki keterkaitan dengan pencapaian standar kompetensi dan kompetensi dasar. Prinsip konsistensi artinya adanya kesamaan antara bahan ajar dengan kompetensi dasar yang harus dikuasai peserta didik. Prinsip kecukupan artinya materi yang diajarkan hendaknya cukup memadai dalam membantu peserta didik menguasai kompetensi dasar yang diajarkan. Materi tidak boleh terlalu sedikit, dan tidak boleh terlalu banyak. Jika terlalu sedikit akan kurang membantu mencapai standar kompetensi dan kompetensi dasar.

Pengembangan materi pembelajaran yang diampu secara kreatif ini meliputi; Kompetensi profesional guru dalam menyampaikan materi pelajaran, menghubung-kan dengan kehidupan riil peserta didik sehari-hari, proses pembelajaran menggunakan lebih dari satu buku rujukan yang relevan, memprogramkan media pembelajaran disesuaikan dengan tujuan, materi, dan karakteristik peserta didik, melibatkan peserta didik dalam pemanfaatan media pembelajaran, memberi kesempatan kepada peserta didik untuk belajar sesuai dengan tingkat perkembangan dan kemampuannya, menggunakan lingkungan sebagai sumber belajar, melaksanakan tindak lanjut dari hasil evaluasi dalam bentuk remedial dan pengayaan, memanfaat-kan hasil penilaian untuk perbaikan pembelajaran, memberikan kesempatan bagi perkembangan kreatifitas peserta didik dalam pembelajaran.

d. Pengembangan keprofesionalan secara berkelanjutan dengan melakukan tindakan reflektif

Hasil analisis deskriptif data tentang kompetensi profesional guru dalam hal pengembangan keprofesionalan secara berkelanjutan dengan melakukan tindakan reflektif, setelah diolah dan dianalisis dalam bentuk tabel frekuensi dan persentase. Dengan berlakunya Undang-undang RI Nomor 14 tahun 2005 tentang Guru dan Dosen diharapkan memberikan suatu kesempatan yang tepat bagi guru untuk meningkatkan profesionalismenya melalui pelatihan, penulisan karya ilmiah, pertemuan di Kelompok Kerja Guru (KKG), dan pertemuan di Musyawarah Guru Mata Pelajaran (MGMP). Hal ini sejalan dengan amanat Undang-undang RI Nomor 20 tahun 2003 tentang Sistem Pendidikan Nasional pasal 10: Pemerintah dan Pemerintah Daerah berhak mengarahkan, membimbing, membantu, dan mengawasi penyelenggaraan pendidikan sesuai dengan peraturan perundang-undangan yang berlaku. Dengan demikian pemerintah mempunyai tanggung jawab yang besar dalam menjadikan pendidikan bermutu, dimana guru adalah 
salah satu sumber daya yang harus dilayani atau dimudahkan dalam mempersiapkan diri menjadikan pendidikan yang berkualitas, misalnya memfasilitasi kemudahan guru adalah bantuan bimbingan dan pemberdayaan guru melalui KKG/MGMP. Dengan demikian KKG dan MGMP memiliki peran yang sangat penting dalam mendukung pengembangan profesional guru. Artinya pertemuan sesama guru pada forum tersebut sebagai perwujudan pemberdayaan setiap guru membentuk pribadi yang kompeten dan profesional, untuk itu di perlukan kolaborasi antar guru, keterbukaan dan membangun komunikasi lewat berbagai kegiatan profesional dalam pengembangan diri.

Pengembangan keprofesionalan secara berkelanjutan dengan melakukan tindakan reflektif ini meliputi: Kompetensi profesional guru dalam hal memberikan kuis/pertanyaan sesuai dengan indikator untuk mengetahui tingkat ketercapaian tujuan pembelajaran, mengadakan analisis karakteristik peserta didik sebelum mengajar, membuat/merancang media pembelajaran sendiri, memeriksa kesiapan peserta didik sebelum memulai pembelajaran, memberikan apresiasi terhadap prestasi yang dicapai peserta didik, mengupayakan partisipasi aktif peserta didik selama proses pembelajaran, dalam proses pembelajaran, berupaya memusatkan perhatian peserta didik, berupaya melibatkan keterampilan/skill peserta didik secara maksimal dalam pembelajaran, memupuk perilaku positif peserta didik terhadap pembelajaran, serta memanfaatkan hasil penilaian untuk perbaikan pembelajaran.

\section{Pengaruh Komitmen Profesi terhadap Kompetensi Profesional Guru Madrasah Tsanawiyah di Kota Makassar}

Hasil penelitian menunjukkan bahwa adanya pengaruh positif komitmen profesi terhadap kompetensi profesional guru. Dari hasil menunjukkan adanya pengaruh yang positif signifikan komitmen profesi terhadap kompetensi profesional guru dengan tingkat signifikansi dibawah 0,05 (p 0,000), ini menunjukkan hipotesis 1 ditolak yang berarti hipotesis 2 diterima. Artinya bahwa komitmen profesi berpengaruh positif terhadap kompetensi profesional guru. Dengan demikian berarti semakin tinggi komitmen profesi guru akan semakin mempengaruhi kompetensi profesionalnya, sebab guru yang me-mahami peraturan perundangan tentang pendidikan, memiliki niat untuk memajukan pendidikan, akan berupaya menjalankan kompetensi profesional dengan maksimal. Dengan kata lain semakin tinggi komitmen profesi guru maka akan semakin profesio-nal guru dalam menjalankan kompetensi profesionalnya.

Berdasarkan hasil uji hipotesis, "Ada pengaruh yang signifikan dari komitmen profesi terhadap kompetensi profesional guru." Setelah dilakukan regresi antara variabel komitmen profesi terhadap kompetensi profesional guru, diperoleh "R Square" atau koefisien determinasi sebesar 0,813 yang berarti 81,3\% kompetensi profesional dapat dijelaskan oleh variabel komitmen profesi. Sedangkan sisanya $(100 \%-46,9 \%=18,7 \%)$ dijelaskan oleh sebab-sebab lain.

Dari hasil uji statistik Regresi, diperoleh F hitung 468,524 Signifikan pada $\alpha=$ 
0,05, maka model regresi dapat dipakai untuk memprediksi komitmen kerja terhadap kompetensi profesional. Dengan demikian, maka hipotesis pertama pada penelitian ini ditolak dan hipotesis kedua "diterima", yaitu ada pengaruh positif yang signifikan dari komitmen kerja terhadap kompetensi profesional guru.

\section{SIMPULAN}

Komitmen profesi guru Madrasah Tsanawiyah di Kota Makassar pada umumnya berada pada kategori sedang. Ini berarti guru Madrasah Tsanawiyah dalam mengenali profesi, keterikatan dan keterlibatan, rasa memiliki, kesetiaan, dan kebanggaan terhadap profesi berada pada kategori sedang.

Kompetensi profesional guru Madrasah Tsanawiyah di Kota Makassar pada umumnya berada pada kategori sedang. Artinya, guru Madrasah Tsanawiyah dalam hal; 1) Penguasaan materi, struktur, konsep, dan pola keilmuan yang mendukung mata pelajaran yang diampu, 2) Penguasaan Standar Kompetensi dan Kompetensi Dasar, 3) Pengembangan materi pembelajaran yang diampu secara kreatif, serta 4) Pengembangan keprofesionalan secara berkelanjutan dengan melakukan tindakan reflektif belum optimal karena berada pada kategori sedang.

Hipotesis penelitian bahwa terdapat pengaruh positif komitmen profesi terhadap kompetensi profesional guru.

Dari hasil analisis data menunjukkan adanya pengaruh yang positif signifikan komitmen profesi terhadap kompetensi profesional guru dengan tingkat signifikansi di bawah 0,05 ( $\mathrm{p}$ 0,000). Artinya, komitmen profesi berpengaruh positif terhadap kompetensi profesional guru. Dengan demikian berarti semakin tinggi komitmen profesi guru dalam mengenali profesi, keterikatan dan keterlibatan, rasa memiliki, kesetiaan, dan kebanggaan terhadap profesi akan semakin mempengaruhi kompetensi profesionalnya, dalam hal: 1) Penguasaan materi, struktur, konsep, dan pola keilmuan yang mendukung mata pelajaran yang diampu, 2) Penguasaan Standar Kompetensi dan Kompetensi Dasar, 3) Pengembangan materi pembelajaran yang diampu secara kreatif serta 4) Pengembangan keprofesionalan secara berkelanjutan dengan melakukan tindakan reflektif. Dengan kata lain semakin tinggi komitmen profesi guru maka akan semakin profesional guru dalam menjalankan kompetensi profesionalnya.

\section{DAFTAR PUSTAKA}

Ashraf, Ali. Horison Baru Pendidikan Islam. Jakarta: Pustaka Firdaus, 1996.

Danim, Sudarwan. Profesionalisasi dan Etika Profesi Guru Cet.2 Bandung: Alfabeta. 2010 .

Daradjat, Zakiah. Kepribadian Guru. Jakarta: Bulan Bintang, 2005.

Departemen Agama RI. Kumpulan Undang-Undang dan Peraturan Pemerintah RI 
tentang Pendidikan. Jakarta: Direkorat Jenderal Pendidikan Islam, 2007.

Departemen Agama. Menuju Madrasah Mandiri. Jakarta: Direktorat Pendidikan Islam, 2007.

Depatemen Agama. Profil Madrasah Masa Depan. Jakarta: Direktorat Jenderal Pendidikan Islam, 2006.

Ditjen Dikdasmen Depdiknas. Pendekatan Kontekstual (Contextual Teaching and Learning, CTL) Jakarta: Ditjen Dikdasmen, 2002.

Imron, Ibrahim Bafadal \& A. Manajemen Peningkatan Mutu Berbasis Sekolah Malang: Kerjasama FIP UM dan Ditjen-Dikdasmen. 2004.

Kunandar. Guru Profesional, Penerapan Kurikulum Tingkat Satuan Pendidikan (KTSP) dan Sukses dalam Sertifikasi Guru. Jakarta: Rajawali Pers, 2007.

Mulyana, Ace Suryadi \& Wiana. Kerangka Konseptual Mutu Pendidikan dan Pembinaan Kemampuan Profesional Guru. Jakarta: PT. Candimas Metropole. 1992.

Nafis, Ahmadi Syukran. Pendidikan Madrasah: Dimensi Profesional dan Kekinian. (Yogyakarta: LaksBang PRESSindo. 2010.

Panggabean, M.S. "Komitmen Organisasional sebagai Mediator Variabel Bagi Pengaruh Kepuasan Kerja”. Jurnal Bisnis dan Akuntansi, Vol 6. No.1, 2004.

Peraturan Pemerintah RI Nomor 19/2005 tentang Standar Nasional Pendidikan, Pasal 28.

Pidarta, M. Manajemen Pendidikan Indonesia Edisi Revisi, Jakarta: Bina Aksara, 2008.

Restuningdiah, Nurika. Pengaruh Komitmen Profesional terhadap Kepuasan Kerja Guru melalui Komitmen Organisasional Disertasi: Universitas Negeri Malang, 2009.

Rusyan, Tabrani, dkk. Pendekatan dalam Proses Belajar Mengajar. Bandung: Remaja Karya, 1990.

Shaleh, Abdul Rahman. Penyelenggaraan Madrasah. Jakarta: Dharma Bakti, 1981.

Sholeh, Asrorun Ni'am, Membangun Profesionalitas Guru Analisis Kronologis atas Lahirnya UU Guru dan Dosen. Jakarta: Elsas, 2006.

Sugiono. Metode Penelitian Administrasi. Bandung: Alfabeta, 2009.

Supriadi, Dedi. Mengangkat Citra dan Martabat Guru (Yogyakarta: Adicita Karya Nusa, 1999.

Supriadi. Mengangkat Citra dan Martabat Guru. Yogyakarta: Adi Cita Karya Nusa, 1999. 
Undang-Undang Republik Indonesia Nomor 14 Tahun 2005 tentang Guru dan Dosen, Bab III Pasal 7.

Winardi, J. Motivasi Pemotivasian. Jakarta: Raja Grafindo Persada. 2007. 